\title{
Nursing Interventions in the Enhanced Recovery After Surgery: Scoping Review
}

\author{
Intervenções de Enfermagem no programa Enhanced Recovery After Surgery ${ }^{\circledR}$ : scoping review \\ Intervenciones de Enfermería en el Programa Enhanced Recovery After Surgery ${ }^{\circledR}$ : Scoping Review
}

\section{Diana Isabel Arvelos Mendes',"I, Candida Rosa de Almeida Clemente Ferrito', Maria Isabel Rodrigues Gonçalves"}

\author{
'Universidade Católica Portuguesa de Lisboa, Institute of Health Sciences. Lisboa, Portugal.
}

"Hospital da Luz Lisboa. Lisboa, Portugal.

How to cite this article:

Mendes DIA, Ferrito CRAC, Gonçalves MIR. Nursing Interventions in the Enhanced Recovery After Surgery ${ }^{\circledR}$ Scoping Review. Rev Bras Enferm [Internet]. 2018;71(Suppl 6):2824-32. [Thematic Issue: Good practices in the care process as the centrality of the Nursing] DOI: http://dx.doi.org/10.1590/0034-7167-2018-0436

Submission: 06-18-2018 Approval: 07-29-2018

\begin{abstract}
Objective: To identify the Nursing interventions, described in literature, in the ERAS ${ }^{\circledast}$ program. Method: We defined a scoping review based on the recommendations of The Institute Joanna Brigs (JBI) and on research in electronic databases. We chose the studies through flow diagrams "Preferred Reporting Items for Systematic Reviews and Meta-Analyses (PRISMA)" and presented them in a chart. Results: We found 306 articles published between 2010 and 2018 and included 14 of them. The main results were: the crucial role nurses play throughout the surgical process, which begins at the preoperative nursing consultation; goes to post-operative care, such as early giving food to patients, effective management of pain or early mobilization; and ends in telephone follow-up. Conclusion: The introduction of the surgical program ERAS ${ }^{\varpi}$ may be an opportunity for nurses to play a more influential role in the surgical path, directly involving with their clients' results.
\end{abstract}

Descriptors: Perioperative Nursing; Nursing; Recovery; Preoperative Nursing; Nursing Care.

\section{RESUMO}

Objetivo: Identificar as intervenções de Enfermagem no programa ERAS ${ }^{\circledast}$ descritas na literatura. Método: Foi elaborada uma scoping review com base nas recomendações do The Institute Joanna Brigs (JBI) e na pesquisa em bases de dados eletrônicas. Os estudos foram selecionados através de diagramas de fluxo Preferred Reporting Items for Systematic Reviews and MetaAnalyses (PRISMA) e apresentados em um quadro. Resultados: Foram encontrados 306 artigos publicados entre 2010 e 2018 , tendo-se incluído 14 deles. Os principais resultados são: o papel crucial que o enfermeiro desempenha ao longo de todo o processo cirúrgico, começando na consulta de Enfermagem pré-operatória, passando pelos cuidados pós-operatórios como a introdução precoce da alimentação, gestão eficaz da dor ou mobilização precoce e terminando com o follow-up telefônico. Conclusão: A implementação do programa cirúrgico ERAS ${ }^{\circledast}$ pode ser uma oportunidade para o enfermeiro desempenhar um papel mais influente no percurso cirúrgico, envolvendo-se diretamente nos resultados do cliente.

Descritores: Enfermagem Perioperatória; Enfermagem; Recuperação; Enfermagem Pré-Operatória; Cuidados de Enfermagem.

\section{RESUMEN}

Objetivo: Identificar las intervenciones de Enfermería en el programa ERAS ${ }^{\circledast}$ descriptas en la literatura. Método: Se elaboró una Scoping Review basada en las recomendaciones del Institute Joanna Brigs (JBI) y con investigación en bases de datos electrónicas. Los estudios fueron seleccionados a través de los diagramas de flujo de los Preferred Reporting Items for Systematic Reviews and Meta-Analyses (PRISMA) y presentados en un marco. Resultados: Se han encontrado 306 artículos publicados entre 2010 y 2018, habiéndose incluido 14 de ellos. Los principales resultados son: el papel crucial que el 
enfermero desempeña a lo largo de todo el proceso quirúrgico, empezando en la consulta de enfermería preoperatoria, pasando por los cuidados post-operativos como la introducción temprana de la alimentación, la gestión eficaz del dolor o la movilización precoz y, terminando con el seguimiento telefónico. Conclusión: La implementación del programa quirúrgico ERAS $^{\circledast}$ puede ser una oportunidad para que los enfermeros desempeñen un papel más influyente en el recorrido quirúrgico, involucrándose directamente en los resultados del cliente.

Descriptores: Enfermería Perioperatoria; Enfermería; Recuperación; Enfermería Preoperatoria; Cuidados de Enfermería.

\section{INTRODUCTION}

The Enhanced Recovery After Surgery ${ }^{\oplus}\left(\right.$ ERAS $\left.^{\oplus}\right)$ program is allusive to perioperative care and includes a set of evidencebased guidelines with a multimodal approach ${ }^{(1)}$ associated with the areas of Surgery, Anesthesia, Nursing, and Nutrition. In this way, its introduction process presupposes a coordinated multidisciplinary approach, which also has as novelty a more active participation of clients in their recovery process, moving from the sick patient concept to the empowered patient concept ${ }^{(2)}$.

This program has many proven benefits in literature, such as the reduction of hospitalization time (without increasing rates of rehospitalization); reduction of postoperative complications; and reduction of costs for institutions ${ }^{(2-3)}$. These benefits can be achieved through principles such as providing clients with the best possible preoperative condition and management of care during surgery, besides promoting the best postoperative recovery $^{(4)}$.

The ERAS ${ }^{\oplus}$ Society guidelines cover the preoperative, intraoperative and postoperative periods. Regarding the preoperative period, the focus is on clients' training, evaluation and optimization of comorbidities, reduction of fasting before surgery and absence of intestinal preparation. In the intraoperative, the prevalence of laparoscopy as surgical technique, balanced management of intravenous fluids, maintenance of temperature and absence of nasogastric tube and drains are intended. Regarding the postoperative period, early and intensive mobilization, early reintroduction of oral feeding, elimination of opioids and adequate management of symptoms, such as nausea and vomiting $^{(5-6)}$. As for the postoperative period, early and intensive mobilization, early reintroduction of oral feeding, elimination of opioids and adequate management of symptoms, such as nausea and vomiting ${ }^{(5-6)}$.

When introducing the ERAS ${ }^{\circledast}$ program, suggestions are to create protocols adapted to the reality of each hospital. This is done aiming to meet the needs of clients; to promote an adequate control of symptoms; to promote the well-being of clients throughout the surgical process; and to enable them to perform self-care in the postoperative $\operatorname{period}^{(7)}$.

Currently, there are several randomized studies that prove the efficacy of ERAS ${ }^{\circledast}$ guidelines, especially in Colorectal Surgery. These recommendations begin to expand to other specialties such as Gynecology and Urology, among others ${ }^{(8)}$, further increasing the impact of this program on nursing.

Our question for this review, according to the acronym PCC (Population, Concept and Context) was: What are the nursing interventions, described in literature, in the ERAS ${ }^{\circledast}$ program?

\section{OBJECTIVE}

To identify the nursing interventions, described in literature, in the ERAS ${ }^{\circledast}$ program.

\section{METHOD}

\section{Ethical Aspects}

A review study implies the reliability and fidelity of information contained in the original documents that support it. Thus, these aspects were ensured through the rigor of the research methodology carried out, proper reference and accuracy in the treatment and presentation of data.

\section{Theoretical-methodological Reference}

The reference used for this review was The Joanna Briggs Institute for Scoping Reviews ${ }^{(9)}$.

\section{Type of Study}

This study is a Scoping Review; a systematized, exploratory review that aims to identify relevant scientific production in a given area, in this case Nursing.

\section{Methodological Procedures}

The first step taken was a generic search in electronic databases such as MEDLINE and SCielo; the second step allowed us to identify the descriptors of this theme and, from them, identify the descriptor MeSh "Perioperative Nursing". Since the objective of the study is to determine specific aspects of Nursing and the ERAS ${ }^{\circledast}$ program, the other element used to cross search with the descriptor "Nursing" was "Enhanced Recovery After Surgery". The third step consisted of research in several electronic databases, through the online platform EBSCOhost.

\section{Data sources}

We selected the MEDLINE and CINAHL databases with full text, Nursing Reference Center, Scopus and B.on. The period chosen was from 2010 to 2018.

\section{Data collection and organization}

We defined articles written in English and Portuguese as inclusion criteria; quantitative and qualitative studies and studies addressing the role and/or interventions of nurses inserted in the ERAS $^{\circledast}$ program. To systematize the process of inclusion of studies, we opted for the PRISMA methodology ${ }^{(10)}$. The selection of articles is presented in a flow diagram (Figure 1). 


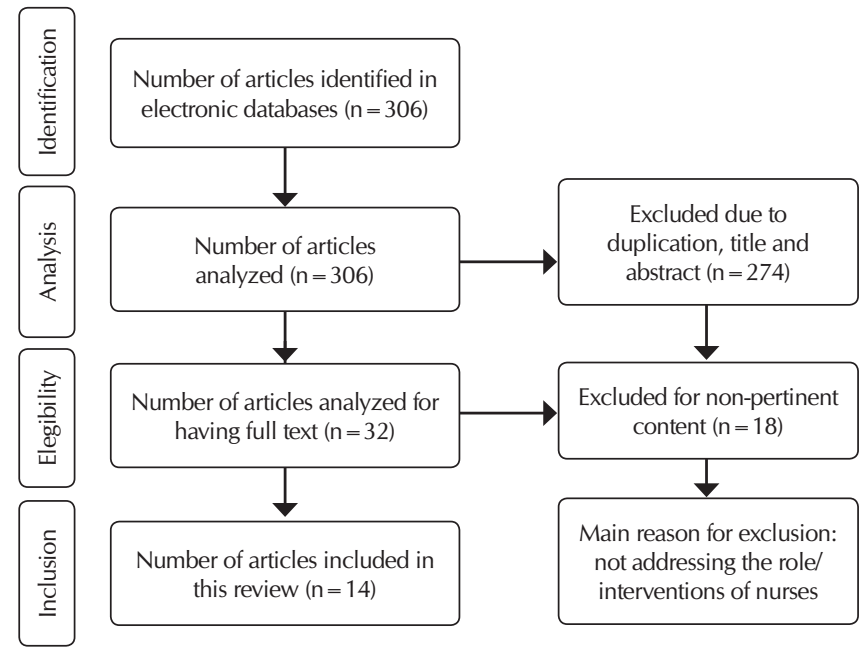

Figure 1 - Process of identification and inclusion of studies Preferred Reporting Items for Systematic Reviews and Meta-Analyses (PRISMA) flow diagram

\section{RESULTS}

After evaluating and selecting articles, 14 papers were included in the scoping review. The significant discrepancy between the number of articles identified in the initial study and those included in the study is largely because most of the articles that address ERAS ${ }^{\circledast}$ do not highlight the role/interventions of nurses in the program. Of the articles included, we highlight that all are English-written, one is from 2010, one from 2011, two from 2012, three from 2014, three from 2015, one from 2016 and three from 2017. We point out the prevalence of qualitative studies (five of them), followed by comparative retrospective studies (four), bibliographical reviews (three) and opinion articles with theoretical basis (two).

The data of the studies is presented in a chart (Chart 1), which identifies some of the characteristics of the study, such as title, year, objective, population/sample, method used and main conclusions ${ }^{(9)}$.

Chart 1 - Presentation of the results of research

\begin{tabular}{|c|c|c|c|c|c|c|}
\hline & Article & Year & Objective of the study & $\begin{array}{l}\text { Population/ } \\
\text { sample }\end{array}$ & $\begin{array}{l}\text { Design of the } \\
\text { study }\end{array}$ & Main conclusions \\
\hline A1 & $\begin{array}{l}\text { Ward nurses' experience } \\
\text { of enhanced recovery } \\
\text { after surgery: a grounded } \\
\text { theory approach }{ }^{(11)}\end{array}$ & 2014 & $\begin{array}{l}\text { Explore and describe the } \\
\text { experiences of nurses } \\
\text { involved in the ERAS } \\
\text { program. }\end{array}$ & 8 nurses & $\begin{array}{l}\text { Qualitative } \\
\text { study - Semi- } \\
\text { structured } \\
\text { interviews }\end{array}$ & $\begin{array}{l}\text { We found } 4 \text { main categories: } \\
\text { believe in the program; introduce } \\
\text { the program; identify the role of } \\
\text { nurses in the program; adapt the } \\
\text { path of clients' recovery. }\end{array}$ \\
\hline $\mathrm{A} 2$ & $\begin{array}{l}\text { The impact of the } \\
\text { enhanced recovery } \\
\text { after surgery (ERAS }) \\
\text { programme on } \\
\text { community nursing } \\
\end{array}$ & 2014 & $\begin{array}{l}\text { Know clients' point } \\
\text { of view to use their } \\
\text { experience in improving } \\
\text { future practice. }\end{array}$ & $\begin{array}{c}\text { Clients of } \\
\text { the ERAS } \\
\text { program }\end{array}$ & $\begin{array}{l}\text { Qualitative } \\
\text { study - Semi- } \\
\text { structured } \\
\text { interviews }\end{array}$ & $\begin{array}{l}\text { Clients need supervision when } \\
\text { returning earlier to home; telephone } \\
\text { follow-up is very well received by } \\
\text { clients; the training of nurses is vital to } \\
\text { the success of the program. }\end{array}$ \\
\hline A3 & $\begin{array}{l}\text { Successful } \\
\text { implementation of an } \\
\text { enhanced recovery after } \\
\text { surgery programme } \\
\text { for elective colorectal } \\
\text { surgery: a process } \\
\text { evaluation of champions' } \\
\text { experiences }^{(13)}\end{array}$ & 2015 & $\begin{array}{l}\text { Know the impact of } \\
\text { introducing the ERAS } \\
\text { program. }\end{array}$ & $\begin{array}{l}58 \text { Health } \\
\text { professionals }\end{array}$ & $\begin{array}{l}\text { Qualitative } \\
\text { study - Semi- } \\
\text { structured } \\
\text { interviews }\end{array}$ & $\begin{array}{l}\text { Nurses can keep up with their } \\
\text { clients' situation throughout their } \\
\text { surgical experience, which helps } \\
\text { nurses to improve their practice } \\
\text { continuously. }\end{array}$ \\
\hline A4 & $\begin{array}{l}\text { Optimising patient } \\
\text { management before } \\
\text { and after surgery }\end{array}$ & 2010 & $\begin{array}{l}\text { Explain the program } \\
\text { and discuss some of its } \\
\text { benefits. }\end{array}$ & - & $\begin{array}{l}\text { Literature } \\
\text { review }\end{array}$ & $\begin{array}{l}\text { Nurses' approach is divided into } \\
4 \text { main moments: preoperative } \\
\text { evaluation; admission; postoperative } \\
\text { and follow-up. It highlights the } \\
\text { concept of clients as partners in care. }\end{array}$ \\
\hline A5 & $\begin{array}{l}\text { Enhanced recovery } \\
\text { after surgery - the } \\
\text { importance of the } \\
\text { perianesthesia nurse on } \\
\text { program success }^{(15)}\end{array}$ & 2017 & $\begin{array}{l}\text { Discuss the importance } \\
\text { of perioperative nurses } \\
\text { in the introduction of the } \\
\text { ERAS }^{\circledast} \text { program. }\end{array}$ & - & $\begin{array}{l}\text { Literature } \\
\text { review }\end{array}$ & $\begin{array}{l}\text { Strong effect of the multidisciplinary } \\
\text { team in the ERAS }{ }^{ø} \text { program; } \\
\text { preoperative training and active } \\
\text { involvement clients as primary } \\
\text { intervention; nurses have a highly } \\
\text { valuable contribution to care. }\end{array}$ \\
\hline A6 & $\begin{array}{l}\text { Facilitators and barriers of } \\
\text { implementing enhanced } \\
\text { recovery in colorectal } \\
\text { surgery at a safety net } \\
\text { hospital: a provider and } \\
\text { patient perspective }^{(16)}\end{array}$ & 2015 & $\begin{array}{l}\text { Identify barriers and } \\
\text { facilitating aspects to the } \\
\text { introduction of an ERAS } \\
\text { program. }\end{array}$ & $\begin{array}{l}19 \text { Health } \\
\text { professionals } \\
18 \text { clients }\end{array}$ & $\begin{array}{l}\text { Qualitative } \\
\text { study - Semi- } \\
\text { structured } \\
\text { interviews }\end{array}$ & $\begin{array}{l}3 \text { major categories: factors related } \\
\text { to professionals; factors related to } \\
\text { clients; and factors related to the } \\
\text { institution. Barriers and events } \\
\text { facilitating the introduction of the } \\
\text { program were identified. }\end{array}$ \\
\hline
\end{tabular}




\begin{tabular}{|c|c|c|c|c|c|c|}
\hline & Article & Year & Objective of the study & $\begin{array}{l}\text { Population/ } \\
\text { sample }\end{array}$ & $\begin{array}{l}\text { Design of the } \\
\text { study }\end{array}$ & Main conclusions \\
\hline A7 & $\begin{array}{l}\text { Effects of a surgical } \\
\text { ward care protocol } \\
\text { following open colon } \\
\text { surgery as part of an } \\
\text { enhanced recovery } \\
\text { after surgery program }\end{array}$ & 2016 & $\begin{array}{l}\text { Assess the effects of } \\
\text { introducing an ERAS } \\
\text { care protocol. }\end{array}$ & 219 clients & $\begin{array}{l}\text { Comparative } \\
\text { retrospective } \\
\text { study }\end{array}$ & $\begin{array}{l}\text { We analyzed aspects such as } \\
\text { recovery of gastrointestinal function, } \\
\text { pain control, recovery time and } \\
\text { postoperative complications. We } \\
\text { emphasize the role of nurses so that } \\
\text { clients achieve positive results. }\end{array}$ \\
\hline A8 & $\begin{array}{l}\text { An integrative review } \\
\text { of postoperative } \\
\text { accelerated recovery } \\
\text { protocols }^{(18)}\end{array}$ & 2017 & $\begin{array}{l}\text { Review published } \\
\text { evidence regarding } \\
\text { perioperative Nursing } \\
\text { care for clients that are } \\
\text { part of the enhanced } \\
\text { recovery protocols. }\end{array}$ & 13 articles & $\begin{array}{l}\text { Integrative } \\
\text { literature } \\
\text { review }\end{array}$ & $\begin{array}{l}\text { It divides the Nursing approach } \\
\text { into two great moments: pre and } \\
\text { intraoperative and postoperative } \\
\text { periods. It emphasizes the importance } \\
\text { of Nursing intervention for the } \\
\text { success of the protocol - client's } \\
\text { outcomes and the importance of } \\
\text { specialized nurses dedicated to care. }\end{array}$ \\
\hline A9 & $\begin{array}{l}\text { Successful } \\
\text { implementation of an } \\
\text { enhanced recovery } \\
\text { pathway: the nurse's } \\
\text { role }^{(19)}\end{array}$ & 2015 & $\begin{array}{l}\text { Describe the role } \\
\text { of nurses in the } \\
\text { introduction of } \\
\text { enhanced recovery } \\
\text { programs. }\end{array}$ & $\begin{array}{c}18 \text { clients } \\
\text { in } 2013 \text { and } \\
15 \text { clients in } \\
2014\end{array}$ & $\begin{array}{l}\text { Comparative } \\
\text { retrospective } \\
\text { study }\end{array}$ & $\begin{array}{l}\text { Stresses the importance of pre- } \\
\text { operative training made by nurses to } \\
\text { clients and their family; importance of } \\
\text { establishing a plan of care appropriate } \\
\text { to the client and ensuring compliance } \\
\text { with the planned surgical path. }\end{array}$ \\
\hline A10 & $\begin{array}{l}\text { Patients as partners } \\
\text { in enhanced recovery } \\
\text { after surgery: a } \\
\text { qualitative patient-led } \\
\text { study }^{(20)}\end{array}$ & 2017 & $\begin{array}{l}\text { Explore the experience } \\
\text { of clients undergoing } \\
\text { colorectal surgery with } \\
\text { the ERAS }{ }^{\otimes} \text { program. }\end{array}$ & 27 clients & $\begin{array}{l}\text { Qualitative } \\
\text { study: focus } \\
\text { group ( } 7 \\
\text { clients) and } \\
\text { interview ( } 20 \\
\text { clients) }\end{array}$ & $\begin{array}{l}\text { One of the aspects pointed out in } \\
\text { the study was how nurses introduce } \\
\text { and encourage compliance with } \\
\text { the ERAS }{ }^{\circledast} \text { protocol in pre-operative } \\
\text { training - clients reveal that it was } \\
\text { through the nurses they received the } \\
\text { most important information. }\end{array}$ \\
\hline A11 & $\begin{array}{l}\text { Enhanced recovery } \\
\text { after surgery: } \\
\text { implications for } \\
\text { nurses }^{(21)}\end{array}$ & 2012 & $\begin{array}{l}\text { Examine practical } \\
\text { aspects of the ERAS } \\
\text { program in relation to } \\
\text { Nursing. }\end{array}$ & - & $\begin{array}{l}\text { Article of } \\
\text { opinion with } \\
\text { theoretical } \\
\text { foundation }\end{array}$ & $\begin{array}{l}\text { The importance of Nursing begins } \\
\text { in preoperative training and also } \\
\text { the concern in the preparation } \\
\text { for discharge. A large part of the } \\
\text { responsibility for introducing the } \\
\text { program is inherent in the role of } \\
\text { nurses. }\end{array}$ \\
\hline A12 & $\begin{array}{l}\text { Patient's need for } \\
\text { nursing telephone } \\
\text { follow up after } \\
\text { enhanced recovery }\end{array}$ & 2012 & $\begin{array}{l}\text { Identify clients' concerns } \\
\text { and discuss their support } \\
\text { needs in this program. }\end{array}$ & $\begin{array}{l}100 \text { clients } \\
\text { of the ERAS } \\
\text { program }\end{array}$ & $\begin{array}{l}\text { Comparative } \\
\text { retrospective } \\
\text { study }\end{array}$ & $\begin{array}{l}\text { About } 50 \% \text { of clients were with } \\
\text { the nurse after discharge from the } \\
\text { hospital, for reasons such as: pain, } \\
\text { stoma care, clarification of doubts, } \\
\text { etc. Telephone follow-up is well } \\
\text { received by clients and has a } \\
\text { positive impact on their vigilance } \\
\text { and confidence levels. }\end{array}$ \\
\hline A13 & $\begin{array}{l}\text { Standardising fast-track } \\
\text { surgical nursing care in } \\
\text { Denmark }^{(23)}\end{array}$ & 2014 & $\begin{array}{l}\text { Report the initiative of } \\
\text { Denmark to increase } \\
\text { the quality of surgical } \\
\text { care by implementing } \\
\text { measures of enhanced } \\
\text { recovery programs. }\end{array}$ & $\begin{array}{c}\text { Audit } \\
\text { platform } \\
\text { data from } 6 \\
\text { countries }\end{array}$ & $\begin{array}{l}\text { Comparative } \\
\text { retrospective } \\
\text { study. }\end{array}$ & $\begin{array}{l}\text { Creation of a perioperative } \\
\text { Nursing unit with well defined } \\
\text { responsibilities. Recognition of } \\
\text { nurses as agents of change and } \\
\text { program auditors - promoting the } \\
\text { creation of guidelines for care. }\end{array}$ \\
\hline A 14 & $\begin{array}{l}\text { The future of surgical } \\
\text { nursing and enhanced } \\
\text { recovery programme }\end{array}$ & 2011 & $\begin{array}{l}\text { Describe the principles } \\
\text { of enhanced recovery } \\
\text { and identify aspects of } \\
\text { Nursing knowledge that } \\
\text { can positively influence } \\
\text { outcomes. }\end{array}$ & - & $\begin{array}{l}\text { Article of } \\
\text { opinion with } \\
\text { theoretical } \\
\text { foundation. }\end{array}$ & $\begin{array}{l}\text { It reports the dynamic approach } \\
\text { that nurses can have in the program } \\
\text { "'accompanying the client" from } \\
\text { preoperative to post-discharge } \\
\text { periods). It reveals that Nursing } \\
\text { should distance itself from } \\
\text { purely physical care and include } \\
\text { interventions coordinated from the } \\
\text { preoperative to the early preparation } \\
\text { for discharge. It is important to } \\
\text { keep the focus on the quality of } \\
\text { information transmitted to clients and } \\
\text { to be aware of the management of } \\
\text { anxiety caused by the surgical process } \\
\text { in clients. Promote coordination with } \\
\text { community nurses to ensure post- } \\
\text { discharge Nursing care. }\end{array}$ \\
\hline
\end{tabular}




\section{DISCUSSION}

Article A1 addresses the experience of nurses in the ERAS program in England and reveals the importance of those involved in believing and knowing the program well, leaving old beliefs about care aside. On the other hand, it emphasizes the role of nurses throughout the program, which begins with a strong training approach - directly associated with a better recovery of clients; some changes in relation to postoperative care, and continuous evaluation and monitoring are highly marked in the role of nurses ${ }^{(11)}$. The main barriers to the introduction of this program were the inconsistency of teams, the lack of individual confidence of nurses and of resources/logistics ${ }^{(11)}$. In general, nurses feel that, with their direct participation in these programs, there is an increase in confidence in their work as well as a feeling of pride in the level of autonomy achieved ${ }^{(11)}$. The multidisciplinary approach is reported as greatly important in the introduction of the programs; however, continuous and coordinated evidence-based nursing care is paramount to the success of these programs ${ }^{(24)}$.

Article A2 highlights the importance of knowing the perspective of clients to promote the improvement of care provided. Thus, the present study shows some of the gaps perceived by clients, namely in terms of training and their specific post-discharge follow-up needs $^{(12)}$. Nursing interventions, such as telephone follow-up, are widely accepted by clients because they increase their level of confidence in recovery and the feeling of accompaniment throughout the surgical process ${ }^{(12)}$. We may infer that training nurses in the program is crucial and, as clients return home earlier, the creation of a community's ERAS ${ }^{\circledast}$ nurse could be important for client's follow-up, and for meeting and giving continuity to the needs of them, part of the enhanced recovery programs.

Article A3 regards the introduction of the ERAS ${ }^{\circledast}$ program; thus, the approach carried out was directly with health professionals. We emphasize that nurses can accompany their clients throughout the entire surgical path and, in this way, perceive the main difficulties/needs felt and expressed by them along the way, which can facilitate the adaptation of protocols to the context and promote a continuous improvement of care $^{(13)}$. However, the willingness to learn and apply new principles that are not traditional is not linear. It is also relevant to create an environment likely to achieve the benefits of the practice suggested by the ERAS ${ }^{\circledast}$ program. Here nurses play a central role in multidisciplinary teams ${ }^{(25)}$.

Article A4 is an opinion article that summarizes nurses' approach throughout the introduction of the program at specific moments, such as the case of preoperative evaluation, strongly marked by clients' training; surgical risk assessment and discharge planning, aspects associated with the pre-qualification concept of the surgical client, which has emerged increasingly as a concern for health professionals ${ }^{(14,26)}$. The article also addresses the admission of clients (complementary to preoperative evaluation); management of postoperative period (ensuring compliance with the guidelines and that clients have the necessary support for their recovery, for example, to manage pain/nausea); and telephone follow-up (contact with clients, allowing the validation of training given, the adaptation to their home, and possible complications) ${ }^{(14)}$. This article also highlights the prevailing role of nurses to introduce the program, so that organizations have been training nurses to be dedicated to this area and to ensure adherence to the protocols, as well as to promote participation and wellbeing of clients throughout the process ${ }^{(14)}$. It is important that during the implementation of the ERAS ${ }^{\circledR}$ program, in addition to creating guidelines to guide nursing care, nurses who are part of the program also give training to other nurses who will provide care and work auditing during the process ${ }^{(27)}$.

Article A5 focuses on generic aspects of introducing the ERAS program and highlights the role of nurses in this process. Nurses are responsible for a large part of training given to clients in the preoperative period. Therefore, nurses interfere directly with the change in attitude of clients - an active role in their recovery ${ }^{(15)}$. The high investment in pre-operative training is a determining factor in recovery; the moment when information is transmitted also greatly affects its assimilation, which must occur a few days before surgery ${ }^{(28)}$. In the present article, the role nurses play in their client's admission day, in the verification of preoperative preparation as well as in the reinforcement of accomplished training is emphasized. Nurses also appear as managers of their clients' postoperative period, with a series of interventions, according to the protocols that directly influence their clients' results ${ }^{(15)}$. Thus, we considered that, with these programs, nurses can directly influence their clients' success before and after surgery, providing follow-up for an enhanced and more adequate recovery.

Study A6 provides a complementary view among health professionals and clients of the ERAS ${ }^{\circledast}$ program $^{(16)}$. Some barriers to introduce the program are highlighted, such as the resistance of professionals to change or non-active participation of clients in their own recovery (for various reasons), such as teamwork, effective communication and structures adapted to the population concerned are identified as key to overcoming barriers ${ }^{(16)}$. We also point out that nurses' knowledge and experience are essential for a system of effective communication in care ${ }^{(17)}$.

Article A7 provides a comparative study of clients' outcomes before and after ERAS ${ }^{\circledast}$ introduction and reveals improved outcomes with the inclusion of protocol measures ${ }^{(17)}$. For the use of protocol measures, all elements of the multidisciplinary team are important; however, nurses have an active role both in training their clients and in directly managing the postoperative period, in several direct interventions they have. Some examples are: earlier mobilization, pain and nausea management, oral recovery, among others. This study reveals the importance of nurses in encouraging self-care and creating clinical protocols that promote the effectiveness of nursing interventions ${ }^{(29)}$. We consider interventions developed by nurses having so great direct influence on their clients' results that the health system should turn to nurses to develop improvement projects ${ }^{(29)}$.

Article A8 presents a synthesis of different published papers, which highlights nurses' role in these enhanced recovery protocols. It presents results according to two moments: preoperative and intraoperative (characterized by clients' training and rigorous evaluation); and postoperative period (with a wide range of interventions that directly affect clients' recovery) ${ }^{(18)}$. In general, roles developed by nurses in the surgical process are again highlighted to achieve satisfactory levels of compliance with these protocols. In this way, nurses' development of knowledge and skills becomes even more important throughout the process, 
by adapting to continuous changes in care delivery, updating frequently and producing scientific evidence ${ }^{(30)}$.

The integration of clients in these enhanced recovery programs foresees a rigorous perioperative care plan, that must be adapted to the needs and characteristics of each client. This is one of the main challenges in structuring/systematizing protocol care ${ }^{(2)}$. Article A9 emphasizes the role of Nursing in delivering client's clinical pathway in these programs, as well as the decisive intervention of training clients and their family, which becomes an intervening part in recovery ${ }^{(19)}$.

Article A10 portrays the strong impact that information transmitted by nurses has on clients and on compliance with the ERAS $^{\circledast}$ protocol $^{(20)}$. Clients acknowledge that most information they received was through nurses and not doctors. Another expressive aspect of the study was preparation for discharge; as clients feel more prepared, with more information, their confidence levels increase, favoring positive results with the program $^{(20)}$. Clients like to have information about what is going to happen during their path, especially what care they should have after discharge. Information, according to their needs and expectations, helps make them feel calmer, which will promote their active participation in the recovery period $^{(31)}$.

Article A11 is an opinion piece; however, we considered it in this study to present pertinent considerations regarding the role of nurses in the introduction of the ERAS ${ }^{\circledast}$ program $^{(21)}$. It focuses on aspects such as the importance of pre-operative training (which is the first moment of preparing client's discharge), as well as nurses' great responsibility in introducing the program, since they are the caregivers who spend most of the time with clients ${ }^{(21)}$. In this article, nurses are even considered as the key element of the ERAS $^{\circledast}$ program, and must also dedicate themselves to research, especially from the point of view of their clients' experiences ${ }^{(21)}$. Currently, it is considered very important to know the client's perspective so that information transmitted is in accordance with what he/she wants to know, constituting an element of balance and not of stress ${ }^{(32)}$. This transmission of information, in addition to being reassuring to the client, will enhance their responsibility throughout the course of surgery and perioperative care ${ }^{(33)}$.

In article A12, the importance of telephone follow-up by nursing professionals with clients of the ERAS ${ }^{\circledR}$ program is highlighted, since they usually have an earlier discharge compared to what is expected for this type of surgery, often increasing the insecurity of returning home ${ }^{(22)}$. With this nursing intervention, clients feel more accompanied and there is opportunity to avoid complications, reinforce trainings and give some emotional support to them ${ }^{(22)}$. These enhanced recovery programs, which allow an earlier discharge, lead to the need for more careful supervision of clients at home, and telephone follow-up is an excellent tool for this purpose ${ }^{(12)}$. The study also showed that roughly $50 \%$ of clients, after discharge, had contact with the nurse of the program and not only with the doctor, emphasizing the role of nurses in the follow-up of their clients, even outside the context of hospitalization.

Article A13 reports Denmark's experience with the creation of a perioperative nursing unit, aiming to create a knowledge center on such enhanced recovery programs; develop a website; build a communication network with other hospitals in the country; organize annual conferences; promote workshops on the most important topics; build, spread and implement care guidelines; and publish results ${ }^{(23)}$. The study recognizes another relevant role of nurses in these programs: they are agents of change and auditors of the process ${ }^{(23)}$. It compares the positive results among some hospitals, regarding, for example, the number of hours that clients undergoing surgery spend "out of bed" - intervention dependent on nursing care ${ }^{(23)}$. Overall, the experience of Denmark, based on the innovative creation of this perioperative nursing unit, promotes the development of nurses' knowledge and skills, leading to the optimization of care provided to surgical clients.

Finally, article A14 highlights the importance of the role of nurses as active members to transmit information to their clients ${ }^{(4)}$. Nurses also reinforce the initial approach in the preoperative period, with a view to plan discharge and the need for a dynamic view of the client's path, to respond to their continuous information needs and help in the control of anxiety over of the process ${ }^{(4)}$. In addition, the article shows that it would be interesting to decentralize nurses' attention to the physical aspects of the process and to plan an integrated and coordinated care intervention from preoperative to post-discharge periods. The author also points out the importance of articulation with nurses of the community for earlier discharge and intervention in the insecurity felt by clients during the postoperative period $^{(4)}$. Given the predictable early discharge, some hospitals also choose to create a nursing support hotline. This would give clients the chance to clarify doubts and have some support and information tailored to their needs, reducing their anxiety and minimizing unnecessary displacement to the hospital ${ }^{(7)}$.

Overall, Nursing has a very important and visible role in enhanced recovery programs, especially in the ERAS ${ }^{\circledast}$ program, expanding its performance throughout the entire surgical path of clients. Nurses have room for direct interventions in the preoperative period, such as in pre-operative nursing consultation, during hospitalization with the follow-up of postoperative care guidelines, and after discharge with client surveillance and follow-up through the telephone, for example.

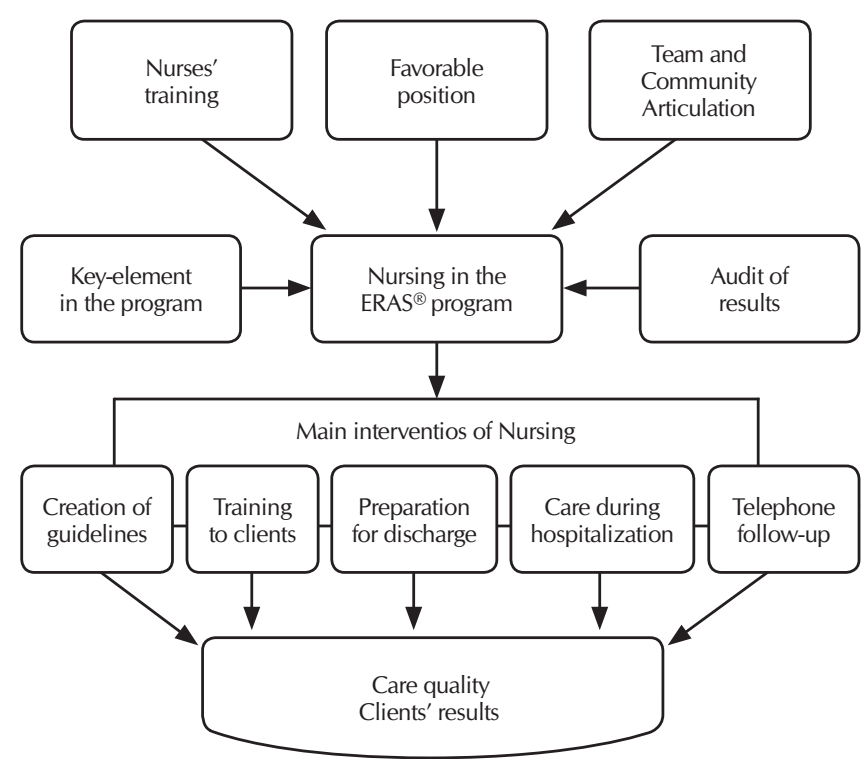

Figure 2 - Synthesis of the main results of mentioned studies 
The main results extracted from the 14 articles included in this review are summarized in the following diagram (Figure 2), highlighting the specific aspects of the role/interventions of Nursing in the ERAS ${ }^{\circledast}$ program.

Factors such as the individual training of nurses, the privileged position they occupy with their clients and the articulation with the multidisciplinary team and the community directly affect the role of Nursing in the ERAS ${ }^{\oplus}$ program. In this context, nurses are considered the key elements of the process by accompanying clients from the preoperative to the postoperative period, over all phases. Nurses are also responsible for auditing the ERAS program, since they have privileged access to the opportunity of improving health care. Basic nursing interventions, associated with the ERAS ${ }^{\circledast}$ program, are based on creating guidelines related to training clients; preparing for discharge; providing care during hospitalization; and following-up in post-discharge through telephone. Several studies demonstrate the influence that these interventions have, directly on improving the quality of health care provided to clients and, consequently, the positive impact on their clients' results.

\section{Study limitations}

We considered as limitations that only studies in Portuguese and English were included in this review, as well as studies that were available in full text, which may have excluded other studies with possible important results for research.

Contributions to the nursing, health or public policy sectors

The results of the present review allowed us to identify the main Nursing interventions in the ERAS ${ }^{\circledast}$ program and to prove the importance that nurses have in the program. This knowledge can contribute to the introduction of the ERAS $^{\circledR}$ program in different institutional contexts and may also inspire future studies that demonstrate the impact Nursing interventions have on the recovery of surgical clients.

\section{FINAL CONSIDERATIONS}

With this review, we could verify that nurses play a significant role to introduce the ERAS ${ }^{\circledast}$ program. Their interventions begin before clients' hospitalization (with preoperative consultation) and continue until after discharge (with telephone follow-up).

Nursing interventions, associated with ERAS ${ }^{\circledast}$, more prominently in literature refer to preoperative training. This aspect can and should constitute a privileged area for the development and production of scientific knowledge in Nursing. Finally, the integration of the ERAS $^{\circledast}$ program is an opportunity to highlight the impact of nurses' performance on the quality of perioperative care, as well as their direct influence on the surgical outcomes of their clients.

\section{REFERENCES}

1. Sibbern T, Bull Sellevold V, Steindal SA, Dale C, Watt-Watson J, Dihle A. Patients' experiences of enhanced recovery after surgery: a systematic review of qualitative studies. J Clin Nurs[Internet]. 2016[cited 2018 May 01];26(9-10):1172-88. Available from: https:// onlinelibrary.wiley.com/doi/full/10.1111/jocn.13456

2. Herbert G, Sutton E, Burden S, Lewis S, Thomas S, Ness A, et al. Healthcare professionals' views of the enhanced recovery after surgery programme: a qualitative investigation. BMC Health Serv Res[Internet]. 2017[cited 2018 May 01];17(1):617. Available from: https://bmchealthservres.biomedcentral.com/articles/10.1186/s12913-017-2547-y

3. Geltzeiler CB, Rotramel A, Wilson C, Deng L, Whiteford MH, Frankhouse J. Prospective study of colorectal enhanced recovery after surgery in a community hospital. JAMA Surg[Internet]. 2014[cited 2018 May 01];149(9):955-61. Available from: https:// jamanetwork.com/journals/jamasurgery/fullarticle/1889569

4. Mitchell M. The future of surgical nursing and enhanced recovery programmes. Brit J Nurs[Internet]. 2011 [cited 2018 May 01];20(16):978-84. Available from: https://www.magonlinelibrary.com/doi/abs/10.12968/bjon.2011.20.16.978

5. Gustafsson UO, Scott MJ, Schwenk W, Demartines N, Roulin D, Francis N, et al. Guidelines for perioperative care in elective colonic surgery: Enhanced Recovery After Surgery (ERAS ) Society recommendations. Clin Nutr[Internet]. 2012 [cited 2018 May 01];31(6):783-800. Available from: https://www.clinicalnutritionjournal.com/article/S0261-5614(12)00180-X/fulltext

6. Subramaniam D, Horgan AF. Enhanced recovery after colorectal surgery: an update on current practice. Surgery-Oxford Int Ed[Internet]. 2016[cited 2018 May 01];35(2):98-101. Available from: https://www.surgeryjournal.co.uk/article/S0263-9319(16)30182-X/fulltext

7. Wennström B, Stomberg MW, Modin M, Skullman S. Patient symptoms after colonic surgery in the era of enhanced recovery-a long-term follow-up. J Clin Nurs[Internet]. 2010[cited 2018 May 01];19(5-6):666-72. Available from: https://onlinelibrary.wiley. com/doi/full/10.1111/j.1365-2702.2009.03099.x

8. Francis NK, Walker T, Carter F, Hübner M, Balfour A, Jakobsen DH, et al. Consensus on training and implementation of enhanced recovery after surgery: a Delphi Study. World J Surg[Internet]. 2018[cited 2018 May 01];1-10. Available from: https://link.springer. com/article/10.1007/s00268-017-4436-2

9. Peters M, Godfrey C, Mclnerney P, Soares C, Khalil H, Parker D. The Joanna Briggs Institute reviewers' manual 2015: methodology for JBI scoping reviews[Internet]. 2015[cited 2018 May 01]. Available from: http://joannabriggs.org/assets/docs/sumari/ Reviewers-Manual_Methodology-for-JBI-Scoping-Reviews_2015_v2.pdf

10. Moher D, Liberati A, Tetzlaff J, Altman DG, Prisma Group. Preferred reporting items for systematic reviews and meta-analyses: the PRISMA statement. PLoS Med[Internet]. 2009[cited 2018 May 01];6(7):e1000097. Available from: http://journals.plos.org/ plosmedicine/article?id =10.1371/journal.pmed. 1000097 
11. Jeff A, Taylor C. Ward nurses' experience of enhanced recovery after surgery: a grounded theory approach. Gastrointestinal Nurs[Internet]. 2014[cited 2018 May 01];12(4):23-31. Available from: https://www.magonlinelibrary.com/doi/abs/10.12968/ gasn.2014.12.4.23

12. Bernard $\mathrm{H}$, Foss $M$. The impact of the enhanced recovery after surgery (ERAS) programme on community nursing. Brit J Community Nurs[Internet]. 2014[cited 2018 May 01];19(4):184-8. Available from: https://www.magonlinelibrary.com/doi/abs/10.12968/ bjcn.2014.19.4.184

13. Conn LG, McKenzie M, Pearsall EA, McLeod RS. Successful implementation of an enhanced recovery after surgery programme for elective colorectal surgery: a process evaluation of champions' experiences. Implement Sci[Internet]. 2015 [cited 2018 May 01];10(1):99. Available from: https://implementationscience.biomedcentral.com/articles/10.1186/s13012-015-0289-y

14. Roberts ], Fenech T. Optimising patient management before and after surgery. Nurs Manag[Internet]. 2010 [cited 2018 May 01];17(6):22. Available from: https://www.ncbi.nlm.nih.gov/pubmed/21137703

15. Crosson JA. Enhanced recovery after surgery: the importance of the perianesthesia nurse on program success. J PeriAnesthesia Nurs[Internet]. 2017[cited 2018 May 01]. Available from: https://www.sciencedirect.com/science/article/pii/S1089947217300400

16. Alawadi ZM, Leal I, Phatak UR, Flores-Gonzalez JR, Holihan JL, Karanjawala BE, et al. Facilitators and barriers of implementing enhanced recovery in colorectal surgery at a safety net hospital: a provider and patient perspective. Surg[Internet]. 2016 [cited 2018 May 01];159(3):700-12. Available from: https://www.surgjournal.com/article/S0039-6060(15)00681-9/fulltext

17. Kim B, Park S, Park K, Ryoo S. Effects of a surgical ward care protocol following open colon surgery as part of an enhanced recovery after surgery programme. J Clin Nurs[Internet]. 2017[cited 2018 May 01];26(21-22):3336-44. Available from: https://onlinelibrary. wiley.com/doi/full/10.1111/jocn.13682

18. Oliveira RA, Silva GMGB, Peniche ADCG, Costa ALS, Poveda VB. An integrative review of postoperative accelerated recovery protocols. AORN J[Internet]. 2017[cited 2018 May 01];106(4):324-30. Available from: https://aornjournal.onlinelibrary.wiley.com/ doi/full/10.1016/j.aorn.2017.08.005

19. Brady KM, Keller DS, Delaney CP. Successful implementation of an enhanced recovery pathway: the Nurse's role. AORN J[Internet]. 2015[cited 2018 May 01];102(5):469-81. Available from: https://aornjournal.onlinelibrary.wiley.com/doi/full/10.1016/j. aorn.2015.08.015

20. Gillis C, Gill M, Marlett N, MacKean G, GermAnn K, Gilmour L, et al. Patients as partners in Enhanced Recovery After Surgery: a qualitative patient-led study. BMJ Open[Internet]. 2017[cited 2018 May 01];7(6):e017002. Available from: http://bmjopen.bmj. com/content/7/6/e017002

21. Foss M, Bernard H. Enhanced recovery after surgery: implications for nurses. Brit J Nurs[Internet]. 2012[cited 2018 May 01];21(4):2213. Available from: https://www.magonlinelibrary.com/doi/abs/10.12968/bjon.2012.21.4.221 ?journalCode =bjon

22. Burch J, Taylor C. Patients' need for nursing telephone follow-up after enhanced recovery. Gastrointestinal Nurs[Internet]. 2012[cited 2018 May 01];10(4):51-8. Available from: https://www.magonlinelibrary.com/doi/abs/10.12968/gasn.2012.10.4.51

23. Jakobsen DH, Rud K, Kehlet H, Egerod I. Standardising fast-track surgical nursing care in Denmark. Brit J Nurs[Internet]. 2014[cited 2018 May 01];23(9):471-6. Available from: https://www.magonlinelibrary.com/doi/abs/10.12968/bjon.2014.23.9.471

24. Broughton BL, Baron B, Kiernan M, Baack-Kukreja J, LaFaro VE, Larmon B, et al. Cystectomy-enhanced recovery program: nursing implications. Urol Nurs[Internet]. 2017[cited 2018 May 01];37(1):9-15. Available from: https://www.ncbi.nlm.nih.gov/ pubmed/29240359

25. Clifford T. Enhanced Recovery After Surgery. J PeriAnesthesia Nurs[Internet]. 2016[cited 2018 May 01];31(2):182-3. Available from: https://www.jopan.org/article/S1089-9472(16)00005-8/abstract

26. Burch J. Enhanced recovery, stomas and the community nurse. Brit J Community Nurs[Internet]. 2013[cited 2018 May 01];18(5):21420. Available from: https://www.magonlinelibrary.com/doi/abs/10.12968/bjcn.2013.18.5.214

27. Console Y, Heriot A, Riedel B, Christelis G. Enhanced recovery after surgery: promoting excellence in surgical oncology nursing care. Austral Nurs Midwifery J[Internet]. 2014[cited 2018 May 01];22(2):33. Available from: https://search.informit.com.au/docu mentSummary; $\mathrm{dn}=447816014854186$; res $=$ IELHEA

28. Ljungqvist $\mathrm{O}$, Hausel J, Nygren J, Thorell A, Soop M. Preoperative patient preparation for enhanced recovery after surgery. Transf Alt Transfusion Med[Internet]. 2007[cited 2018 May 01];9(1):45-9. Available from: https://onlinelibrary.wiley.com/doi/ abs/10.1111/j.1778-428X.2007.00045.x

29. Ralph N, Duff J. Enhanced Recovery After Surgery (ERAS) protocols-an opportunity for improved care and enhanced scope of practice? J Perioperative Nurs Austral[Internet]. 2017[cited 2018 May 01];30(2):3-4. Available from: https://www.researchgate. net/profile/Nicholas_Ralph/publication/316785010_Enhanced_Recovery_After_Surgery_ERAS_protocols_-_an_opportunity_for_ improved_care_and_enhanced_scope_of_practice/links/591155e9458515bbcb88a492/Enhanced-Recovery-After-Surgery-ERASprotocols-an-opportunity-for-improved-care-and-enhanced-scope-of-practice.pdf

30. Foss M. Enhanced recovery after surgery and implications for nurse education. Nurs Standard [Internet]. 2011 [cited 2018 May 01];25(45):35. Available from: https://www.ncbi.nlm.nih.gov/pubmed/21850846

31. Mavridou P, Manataki A, Arnaoutoglou E, Damigos D. A survey of patients' preoperative need for information about postoperative pain-effect of previous surgery experience. J PeriAnesthesia Nurs[Internet]. 2017[cited 2018 May 01];32(5):438-44. Available 
from: https://www.jopan.org/article/S1089-9472(16)30201-5/abstract

32. Bernard H, Foss M. Patient experiences of enhanced recovery after surgery (ERAS). Brit J Nurs[Internet]. 2014 [cited 2018 May 01];23(2):100-6. Available from: https://www.magonlinelibrary.com/doi/abs/10.12968/bjon.2014.23.2.100

33. Aasa A, Hovbäck M, Berterö CM. The importance of preoperative information for patient participation in colorectal surgery care. J Clin Nurs[Internet]. 2013[cited 2018 May 01];22(11-2):1604-12. Available from: https://onlinelibrary.wiley.com/doi/full/10.1111/ jocn. 12110 